\title{
Establishment and characterization of new human cell lines for recombinant therapeutic protein production
}

\author{
Yuichi Inoue ${ }^{1}$, Akira Iwamoto ${ }^{2 *}$, Aiko Inoue ${ }^{3}$, Hiroharu Kawahara ${ }^{1}$ \\ From 24th European Society for Animal Cell Technology (ESACT) Meeting: C2P2: Cells, Culture, Patients, Products \\ Barcelona, Spain. 31 May - 3 June 2015
}

\section{Background}

Recombinant therapeutic proteins are increasingly requested with advances in tissue engineering using stem cells. Human cell line is an attractive host for the production of such glycoprotein, but there are few reports on human cells for a commercial production [1]. In this study, we established new human lymphoid cell lines from peripheral blood mononuclear cells (PBMCs) by treatment with phorbol 12-myristate 13-acetate (PMA) under a non-GMP condition, and characterized them by gene and protein expression analyses.

\section{Experimental Approach}

The human PBMCs $(2 \times 106$ cells $/ \mathrm{ml})$ were cultured in 24 well plates in $12.5 \%$ FBS-ERDF medium supplemented with $10 \mathrm{ng} / \mathrm{ml}$ of IL- 4 and/or IL- 6 and $1 \mu \mathrm{g} / \mathrm{ml}$ of PMA for three months. The medium was changed every two or three days.

The gene expression of telomerase reverse transcriptase (TERT), a marker of immortalization, was examined by RT-PCR. The immunoglobulin (Ig) isotype was confirmed by ELISA. The CD markers on cell surface were detected by flow cytometry.

\section{Results and Discussion}

Although normal human cells are difficult to be transformed by chemical reagents such as PMA, we succeeded in obtaining three human cell clones under above condition (Table 1). The key point in our transformation may be continuous stationary culture without passage. All obtained clones were able to be subcultured over one year and were found to express TERT. In addition, they produced any isotype of immunoglobulin in the medium, indicating B lymphocytes. The results of flow cytometry also supported it. Therefore, these clones may be suitable for the production of secreted human glycoprotein because mature $\mathrm{B}$ lymphocytes have the extensive endoplasmic reticulum. In the next step, we will establish GMP compliant new human lymphoid cell lines.

Table 1. Summary of cell establishment and characterization

\begin{tabular}{llll}
\hline & Clone1 & Clone2 & Clone3 \\
\hline Culture medium for transformation & $12.5 \%$ FBS-ERDF +IL-4+IL-6+PMA & $12.5 \%$ FBS-ERDF +IL-6+PMA & $12.5 \%$ FBS-ERDF +IL-4+IL-6+PMA \\
Culture medium for maintenance & $12.5 \%$ FBS-ERDF & $12.5 \%$ FBS-ERDF & $12.5 \%$ FBS-ERDF \\
& $(+P M A)$ & $(+P M A)$ & $(+P M A)$ \\
Possible period of subculture & Over 1 year & Over 1 year & Over 2 years \\
Mean doubling time & 30 hours & 30 hours & 30 hours \\
TERT expression & Positive & Positive & Positive \\
Produced Immunoglobulin & IgG & IgM & IgG \\
B cell marker (CD19) & Positive & Positive & Positive \\
\hline
\end{tabular}

\footnotetext{
* Correspondence: inoue@kct.ac.jp

${ }^{2}$ Department of Bioscience and Biotechnology, Kyushu University, Fukuoka

812-8581, Japan

Full list of author information is available at the end of the article
} 


\section{Acknowledgements}

This work was supported by JSPS KAKENHI Grant Number 26460167.

\section{Authors' details}

${ }^{1}$ National Institute of Technology, Kitakyushu College, Kitakyushu, 802-0985, Japan. ${ }^{2}$ Department of Bioscience and Biotechnology, Kyushu University, Fukuoka 812-8581, Japan. ${ }^{3}$ Department of Clinical Laboratory, Kyurin

Corporation, Kitakyushu 806-0046, Japan.

Published: 14 December 2015

\section{Reference}

1. Swiech K, Picanco-Castro V, Covas DT: Human cells: New platform for recombinant therapeutic protein production. Protein Expr Purifi 2012, 84:147-153.

doi:10.1186/1753-6561-9-S9-P3

Cite this article as: Inoue et al: Establishment and characterization of new human cell lines for recombinant therapeutic protein production. BMC Proceedings 2015 9(Suppl 9):P3.

\section{Submit your next manuscript to BioMed Central} and take full advantage of:

- Convenient online submission

- Thorough peer review

- No space constraints or color figure charges

- Immediate publication on acceptance

- Inclusion in PubMed, CAS, Scopus and Google Scholar

- Research which is freely available for redistribution

Submit your manuscript at www.biomedcentral.com/submit
C Biomed Central 